OPTIMUM. ECONOMIC STUDIES NR 2 (92) 2018

\author{
Lukasz ZEGAROWICZ, MA \\ Faculty of Economics and Management, University of Bialystok \\ e-mail: 1.zegarowicz@uwb.edu.pl
}

DOI: $10.15290 / 0 e s .2018 .02 .92 .12$

\title{
THE PATENT BOX AS AN INSTRUMENT FOR CREATING INNOVATION IN EU COUNTRIES
}

\begin{abstract}
Summary
The purpose of the paper is to present the Patent Box, a tax instrument for creating innovative potential which is becoming increasingly popular in EU economies, and to analyze what impact a Patent Box can have on the level of innovation of a country's economy. To achieve this objective, two research methods are used: critical analysis of the literature and quantitative research. The literature studies involved presenting the operation mechanism of Patent Boxes and justifying (based on the theory of economics) the usage of such instruments in creating the innovation potential of an economy. The quantitative research consisted in analyzing the relationship between Patent Box instruments possessed by individual EU countries within their tax systems in the years 2011-2015 and the level of innovation in these countries expressed as outcome indicators based on the number of patents. The conducted analysis allowed the author to validate the hypothesis that the Patent Box has an effect on the level of innovation in EU countries. In Polish scientific literature there are relatively few publications addressing the issue of the operating mechanisms of the Patent Box or the economic effects resulting from the application of this kind of innovative tax policy tool. Considering the importance of innovation in making economic growth processes more dynamic, there is a need to undertake further research in this scope. The conducted research facilitates exploration of both the theoretical and empirical knowledge of the issue. Its conclusions might also prove useful in the scientific debate concerning the support provided by the state to the private sector in Poland in their efforts to embark on innovative activities.
\end{abstract}

Key words: Patent Box, innovation policy, tax incentive, patent

JEL: O34, O38

\section{Introduction}

In the light of previous research (both theoretical and empirical), the impact of innovation on economic growth seems undeniable [NBP, 2016]. The importance of innovation processes on growth and development was already observed by J. Schumpeter, who believed that "to produce means to combine materials and forces within our reach" [Schumpeter, 1960, p. 103], and defined economic growth as the process of creating new combinations of production factors. M. Abramowitz and R. Solow ascribed long-term economic growth to 
the factor of widely perceived productivity [Abramowitz, 1956; Solow, 1957]. K. Arrow, P. Romer, G. Grossman, and E. Helpman - the creators of endogenous growth models - as well as P. Aghion and P. Howitt, attached even greater importance to innovation. Not only did all these authors draw attention to the essence of innovation as a determinant of long-term economic growth, but they also stressed that innovation could be stimulated by investments in research and development, education, creation of new knowledge, and training [Arrow, 1962; Romer, 1986; Grossman, Helpman, 1991; Aghion, Howitt, 1992].

The results of scientific research which place ever greater emphasis on the significance of innovation for the processes of economic growth and development have also been followed by appropriate economic policies. Since the second half of the 20th century, Western European countries have been adopting innovation policies aimed at stimulating their economies' innovation potentials. For the last 15 years, increasing importance has been attached to indirect forms of pursuing innovative policies, with tax incentives as the leading element [European Commission, 2009].

The aim of this paper is to present the Patent Box, a tax instrument for creating back-end innovation potential, which in recent years has been gaining popularity in the countries of the European Union. Another aim is to analyze the relationship between the presence of such instruments as a Patent Box in a tax system and the innovation levels of EU economies. The importance of the subject of such tax incentives results not only from the possibility of using them for stimulating innovation, but also from the threats resulting from their role in international (often illegal) tax optimization [Alstadsæter et al., 2015].

\section{Mechanism of Patent Box-type incentives}

The Patent Box, also referred to as the Innovation Box, first appeared in France and Ireland as early as in the 1970s. Interestingly, Ireland is also the first, and so far only, country to abandon the Patent Box. It was removed from the Irish tax system in 2010 due to budget problems, but was introduced again in January 2016 [Alstadsæter et al., 2015]. Since the early years of the 21st century the number of countries that adopted this instrument has been increasing systematically. In February 2016, as many as 13 EU countries possessed Patent Box-type tools, which constitutes almost half of the member states.

In order to thoroughly comprehend the mechanism of such instruments as the Patent Box, it is first necessary to consider the purpose of introducing them into the tax regimes of particular countries. The tasks set for the Patent Boxes in European countries vary: they can either have economic or fiscal aims. Economic purposes include supporting the formation of domestic innovations and creation of new jobs. The fiscal purposes, on the other hand, consist in reducing the erosion of the tax base: high taxation of incomes from intellectual property may motivate economic entities to register the sources of incomes in 
jurisdictions characterized by relatively lower taxation of revenues, e.g. in tax havens [Bradley et al., 2015].

Depending on the stage of the innovative process, tax instruments used in innovation policies can be divided into two types: front-end and back-end (figure 1). The former include tax preferences related to incurring outlays on innovative activity. Therefore, they regard the initial stage of the innovation process, one in which the costs of the activity are incurred [Wildowicz-Giegiel, Dziemianowicz, 2015]. Among these, there are three types of instruments: accelerated amortization of the assets used in innovation activity, lower social insurance contributions of employees involved in the creation of innovation, and allowances, the amount of which is dependent on the value of the outlays on innovation (chiefly research and development). The allowance can either take the form of a deduction from the tax base or a direct reduction of the tax due.

The Patent Box falls into the category of back-end tax incentives. Instruments of this type concern the final stage of the innovation process, i.e. generating revenue. Their operation mechanism consists, therefore, in preferential taxation of revenues derived from innovation activity. In this case, the preferences can be expressed in lowered tax rates, or temporary (income tax holidays), or even complete exemption from the obligation to pay income tax in the case of some revenues from innovation activity.

FIGURE 1

\section{Division of tax instruments used in innovation policies according to stage of innovation process}

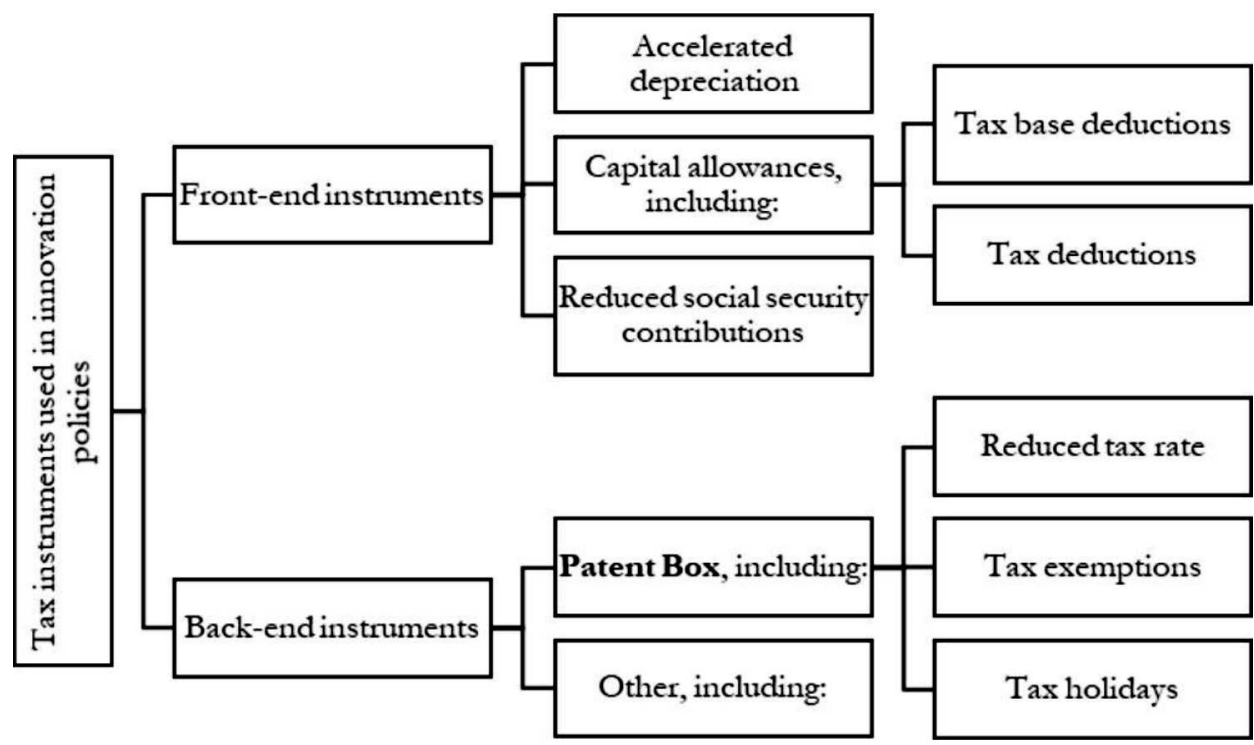

Source: own elaboration. 
Instruments such as the Patent Box involve using preferential tax rates in relation to certain types of revenue from intellectual property or even their exclusion from taxation [Merril, 2016]. Preferential taxation of income from intellectual property contributes to the accumulation of benefits reaped by a company from creating and patenting new knowledge (figure 2).

FIGURE 2

Accumulation of market advantage thanks to Patent Box
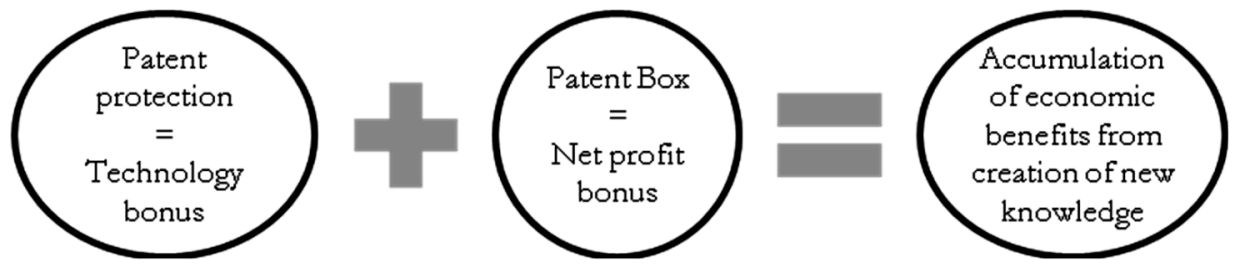

Source: own elaboration.

Patent protection of new products or technologies in itself enables companies to achieve competitive advantages thanks to temporary technology bonuses. In those economies which adopt a Patent Box, companies achieve additional advantages in the form of increased net revenues from their innovation activity thanks to the preferential taxation of incomes from the sale of the rights to new knowledge. The accumulation of economic benefits results in increased profitability of the research and development sector, consequently strengthening the interest of the private sector in creating new knowledge.

The macroeconomic effects resulting from the application of the Patent Box can be either positive or negative. Among the positive consequences on a macro scale one can mention: greater interest in innovation, possible increase in employment in the research and development sector, possible inflow of foreign investments related to creation of new knowledge, reduced erosion of the tax base, possible increase in tax income thanks to increased volume of intellectual property in circulation, acceleration of the phenomenon of innovation diffusion (imitation) through encouraging companies to sell rights to new knowledge. On the other hand, the negative economic effects can include: a reduction of tax income, intensification of the phenomena of international tax competition and transfer of profits, as well as tax evasion on the international scale, the disturbance of the mechanism of market competition in the market of new products [European Commission, 2014].

Economic practice shows that the construction of the Patent Box is extremely diversified, even across countries belonging to such an economically and politically integrated international organization as the European Union (table 1). The range of preferential taxation can comprise only income from patents (Malta, Greece), be extended to a minimum degree (Belgium, Cyprus, the Netherlands, Ireland, Portugal), or be extended to most income from intel- 
TABLE 1

\section{Patent Box in selected countries of European Union (as of February 2016)}

\begin{tabular}{|c|c|c|c|c|}
\hline Country & $\begin{array}{c}\text { Year of } \\
\text { introduction }\end{array}$ & $\begin{array}{l}\text { Basic } \\
\text { CIT rate }\end{array}$ & $\begin{array}{l}\text { Effective } \\
\text { CIT rate }\end{array}$ & Range \\
\hline Belgium & 2007 & $33.99 \%$ & $6.8 \%$ & $\begin{array}{l}\text { Patents and complementary } \\
\text { certificates }\end{array}$ \\
\hline Cyprus & 2012 & $12.5 \%$ & $2.5 \%$ & $\begin{array}{l}\text { Patents, copyrights, trade marks } \\
\text { and service marks }\end{array}$ \\
\hline France & $2001^{*}$ & $33.33 \%$ & $15.5-17.1 \%$ & $\begin{array}{l}\text { Patents, extended certificates, } \\
\text { patent inventions, industrial } \\
\text { production processes }\end{array}$ \\
\hline Greece & 2011 & $29 \%$ & $0 \%$ & Patents \\
\hline Spain & $2013^{*}$ & $25 \%$ & $12-15.6 \%$ & $\begin{array}{l}\text { Patents, processes, plans, models, } \\
\text { designs, know-how }\end{array}$ \\
\hline Netherlands & 2007 & $25 \%$ & $5 \%$ & $\begin{array}{l}\text { Patents and IP from approved } \\
\text { R\&D projects }\end{array}$ \\
\hline Ireland & $2016^{*}$ & $12.5 \%$ & $6.25 \%$ & Patents and computer programs \\
\hline Luxembourg & 2008 & $29.22 \%$ & $5.76 \%$ & $\begin{array}{l}\text { Patents, trademarks, designs, } \\
\text { names of domains, models, } \\
\text { software }\end{array}$ \\
\hline Malta & 2010 & $35 \%$ & $0-6.25 \%$ & Patents \\
\hline Portugal & 2014 & $21 \%$ & $11.5 \%$ & $\begin{array}{l}\text { Patents, models, industrial } \\
\text { patterns }\end{array}$ \\
\hline Hungary & 2003 & $19 \%$ & $5-9.5 \%$ & $\begin{array}{l}\text { Patents, know-how, trade marks, } \\
\text { names of companies, trade secrets, } \\
\text { copyrights }\end{array}$ \\
\hline Great Britain & 2013 & $20 \%$ & $10 \%$ & $\begin{array}{l}\text { Patents, certificates of additional } \\
\text { protection, protection of personal } \\
\text { data, plant varieties }\end{array}$ \\
\hline Italy & 2015 & $31.4 \%$ & $18.84 \%$ & $\begin{array}{l}\text { Patents, trade marks, software, } \\
\text { models, designs, know-how, } \\
\text { processes, licensed IP }\end{array}$ \\
\hline
\end{tabular}

* Patent Box has existed in French and Irish tax systems since early 1970s. It was introduced into the Spanish tax system in 2008. Owing to considerable changes in its construction or temporary intervals in the functioning of the instrument, the year included in the table represents the beginning of the instrument's existence in these countries in its current form.

Source: own elaboration based on: [Global Research..., 2016; Corporate tax..., 2017; Koimtzoglu, Lytras, 2015; Cyprus a..., 2012].

lectual property (France, Spain, Luxembourg, Hungary, Great Britain, Italy). Apart from the basic types of tax preferences regarding intellectual property, such as patents, trade marks, certificates and know-how, there are also less frequently used instruments that apply preferences also to income from: names of 
Internet domains (Luxembourg), names of companies and trade secrets (Hungary) or the rights to cultivate certain varieties of plants (Great Britain). The scales of preferences also vary. The least effective tax rates within the framework of the Patent Box are used in Malta and Greece, where certain revenues from patents are even subject to tax exemption. Relatively low rates in terms of their effectiveness exist in Belgium, Cyprus, the Netherlands, Luxembourg, and Hungary. In these countries, the income related to the Patent Box is subject to taxation, the rates of which are more than twice as low as in the case of other sources of revenue. In France, Spain, Ireland, Portugal, Great Britain, and Italy, the effective tax rates within the framework of the Patent Box are usually not lower than fifty percent of the basic CIT rate.

\section{Research methodology}

The aim of the conducted research was to verify the correctness of the hypothesis that the use of the Patent Box in a tax system has an impact on the level of innovation in the countries of the European Union. Therefore, analysis was required of two elements of economic reality: the use of the Patent Box by particular countries and the changes in the innovation levels of the analyzed countries in the studied period. Additionally, it proved necessary that the existence of a relationship between the analyzed factors be verified and its direction and intensity specified. The research included $27^{1} \mathrm{EU}$ countries. The only EU member state not analyzed was Slovenia ${ }^{2}$. The analysis comprised the years 2011-2015 ${ }^{3}$.

The analyzed countries were divided into two groups (table 2): those which adopted Patent Boxes in the analyzed period and those which did not. The classification criterion was the functioning of the Patent Box in the tax system of the analyzed country continuously in the years 2011-2015. The countries which fulfilled this criterion were classified into the first group. The second group includes countries that did not have Patent Boxes in their tax systems in that period or did so only during a part of the analyzed time interval. These criteria result from the necessity to consider in the analysis the possible time

1 The analyzed countries: Austria (AT), Belgium (BE), Bulgaria (BG), Croatia (HR), Cyprus (CY), Czech Republic (CZ), Denmark (DK), Estonia (EE), Finland (FI), France (FR), Germany (DE), Greece (GR), Hungary (HU), Ireland (IE), Italy (IT), Latvia (LV), Lithuania (LT), Luxembourg (LU), Malta (MT), The Netherlands (NL), Poland (PL), Portugal (PT), Romania (RO), Slovakia (SK), Spain (ES), Sweden (SE) and Great Britain (GB).

2 Data regarding patent activity in Slovenia after 2011 are not available, which made it impossible to include this country in the analysis.

3 Selection of the time period was determined by the availability of data on Patent Box in EU countries and data regarding the innovation levels of the analyzed economies. The first comprehensive studies of tax incentives for innovation in the international context were published in 2010. The most recent data on patents in the WIPO member countries are from 2015. 
TABLE 2

Classification criteria dependent on use of Patent Box

\begin{tabular}{|l|c|l|}
\hline Group of countries & $\begin{array}{c}\text { Group } \\
\text { number }\end{array}$ & \multicolumn{1}{c|}{ Possible actual state } \\
\hline Using Patent Box & 1. & Continuous use of Patent Box in years 2011-2015 \\
\hline Not using Patent Box & 2. & $\begin{array}{l}\text { Lack of Patent Box in years 2011-2015. } \\
\text { Use of Patent Box for shorter period of time than } \\
\text { since 2011 }\end{array}$ \\
\hline
\end{tabular}

Source: own elaboration.

difference between the introduction of the incentive into the tax system and the occurrence of the economic effects of this move. According to the author, the introduction of a Patent Box later than in 2011 may not have resulted in any increase in innovation level by 2015. For this reason, the countries that included this instrument into their tax systems after 2011 ought to be qualified into the second group.

The innovation level of an economy can be measured using input indicators or output indicators (figure 3). The former reflect the level of expenditures on the creation of innovations (mostly outlays on $R \& D$ ). The indicator may represent global expenditures (GERD), the expenditures of companies (BERD), universities (HERD), governments (GOVERED). Output indicators, on the other hand, reflect selected economic effects that can be associated with the innovative character of the economy. These may include: the number of scientific publications, patent applications and obtained patents, the number of doctorates, or the participation of high-tech industries in the structure of the economy. Additionally, there are synthetic indexes of innovation that include numerous fragmentary indicators, both of input and output type [NBP, 2016].

FIGURE 3

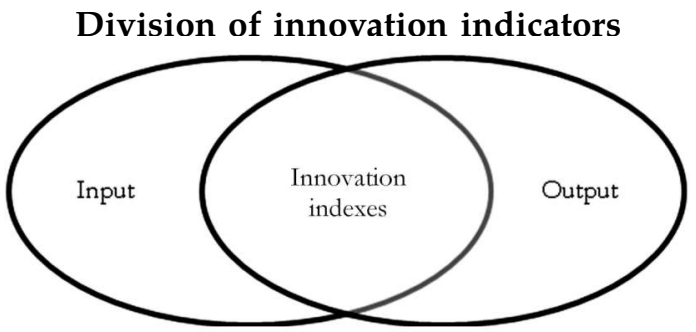

Source: [Potencjat innowacyjny..., 2016, p. 23].

For the purposes of this study, innovation levels were measured using two output indicators based on the number of patents:

- number of patent applications per \$100 bln GDP,

- number of patent applications per $1 \mathrm{mln}$ inhabitants. 
According to the author, the economic effect of innovation processes, i.e. in this case, the creation of new knowledge documented by a patent application, is reflected by output indicators better than by input indicators. Furthermore, the relative form of the indicator enables comparisons and analyses with regard to economies of various sizes. However, one needs to remember that patent indicators reflect only the amount of new knowledge in an economy, not its quality, even though the latter is of vital importance for a comprehensive view of innovative performance. The quality of created innovations cannot be measured on a national scale by means of quantity indicators. Another significant methodological limitation of the adopted indicator is the fact that not every type of knowledge is reported in the patent office and that not every type of knowledge can be regarded as innovation. As a consequence, the number of patent applications may not fully reflect the number of innovations created in an economy.

In order to illustrate the changes in innovation levels over the period in question, a dynamics analysis was also conducted for both innovation indicators on the basis of two measures:

- relative growth of the indicator in years 2011-2015:

$$
W_{2015 / 2011}=\frac{W_{2015}-W_{2011}}{W_{2011}},
$$

where: $W_{2015 / 2011}$ - relative growth in years 2011-2015, $W_{2011}$ - value of indicator in 2011, $W_{2015}$ - value of indicator in 2015,

- average annual growth rate of indicator in years 2011-2015:

$$
W_{G}=\sqrt[4]{\frac{W_{2012}}{W_{2011}} \frac{W_{2013}}{W_{2012}} \frac{W_{2014}}{W_{2013}} \frac{W_{2015}}{W_{2014}}}-1,
$$

where: $W_{G}$ - average annual growth rate in years 2011-2015, $W_{2011}$, $W_{2012}, \ldots$ - value of indicator in year $2011,2012, \ldots$

The value of both measures of dynamics was determined, both separately for each country and for groups of countries with and without Patent Box regimes in the analyzed period. A lack of considerable differences between groups would contradict the hypothesis, whereas their presence will confirm it.

\section{Results}

The popularity of the Patent Box as a basic instrument of innovation policy in the second decade of the $21^{\text {st }}$ century has been considerably increasing (chart 1). In 2011, the instrument was part of the tax systems of 8 countries: Belgium, France, Greece, Spain, the Netherlands, Luxembourg, Malta, and Hun- 
gary. In 2012, this group was joined by Cyprus, and one year later, by Great Britain. In the years 2014 and 2015, the Patent Box was introduced in Portugal and Italy, respectively. In 2016, the group of countries where this instrument was used also included Ireland, i.e. 13 EU member states had adopted the instrument.

\section{Application of Patent Box in EU, years 2011-2015}

\section{CHART 1}

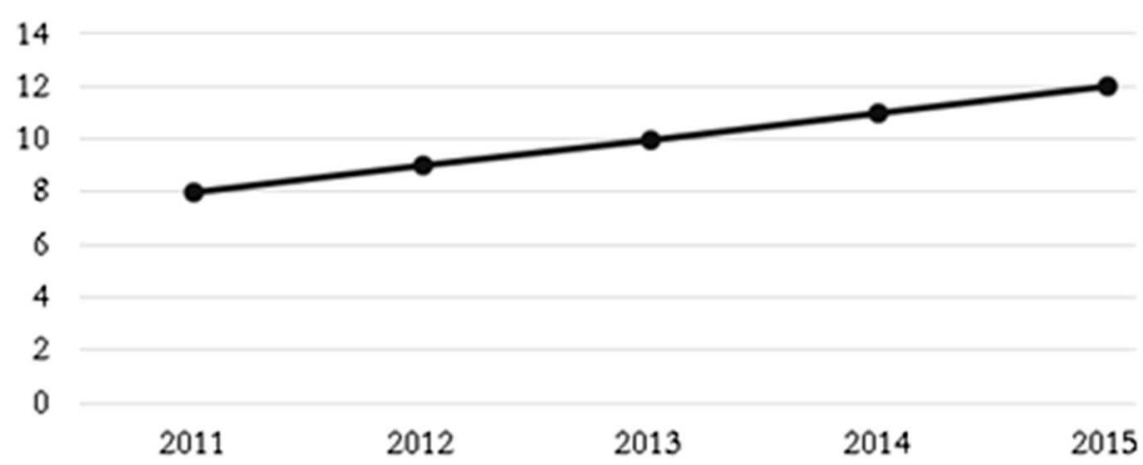

\section{$\rightarrow$ Number of countries with Patent Box in tax system}

Source: own elaboration based on: [2012 Global..., 2012; 2013 Global..., 2013; 2014 Global..., 2014; 2015 Global..., 2015; A Study..., 2014; Global Research..., 2016; Global Survey..., 2011; Worldwide RED..., 2013; Worldwide RED..., 2014].

In accordance with the adopted research methodology, 8 countries which introduced this instrument before 2012 were included in the group of countries using the Patent Box (table 3). Those countries which introduced it in the later period, i.e. Cyprus, Slovakia, Great Britain, Portugal, Italy, and Ireland were qualified into the second group, together with 13 other countries that did not apply such instruments.

TABLE 3

Classification of analyzed countries according to use of Patent Box

\begin{tabular}{|l|c|l|}
\hline Group of countries & $\begin{array}{c}\text { Group } \\
\text { number }\end{array}$ & \multicolumn{1}{c|}{ Countries } \\
\hline With Patent Box & 1. & $\begin{array}{l}\text { Belgium, France, Greece, Spain, the Netherlands, } \\
\text { Luxembourg, Malta, Hungary }\end{array}$ \\
\hline Without Patent Box & 2. & $\begin{array}{l}\text { Austria, Bulgaria, Croatia, Cyprus, Czech Republic, } \\
\text { Denmark, Estonia, Finland, Ireland, Lithuania, Latvia, } \\
\text { Germany, Poland, Portugal, Romania, Slovakia, Sweden, } \\
\text { Great Britain, Italy }\end{array}$ \\
\hline
\end{tabular}

Source: own elaboration. 
The innovation levels of the analyzed countries were characterized by considerable changeability in the years 2011-2015. The country with the largest number of patent applications per $\$ 100$ bln GDP (chart 2) in 2011 was Germany $(2,124)$. The value of an indicator higher than 1,000 in 2011 was also recorded by Finland $(1,485)$, Denmark $(1,398)$, Sweden $(1,359)$, the Netherlands (1058), and Austria (1,052). The lowest level of an indicator in that year was found in Lithuania (157), Cyprus (182), and Slovakia (198). More than 1,000 patent applications per \$100 bln GDP were recorded in 2015 in Germany $(2,014)$, Finland $(1,554)$, Denmark $(1,375)$, Sweden $(1,323)$, the Netherlands $(1,184)$, Austria $(1,111)$, Luxembourg $(1,017)$, and France $(1,006)$. The group of countries with the value of indicators lower than 200 in 2015 did not change in relation to the year 2011. The highest growth of the indicator's value in the years 2011-2015 was observed in Portugal $(+157)$, the Netherlands $(+126)$, and Malta (+109). The largest decrease occurred in the case of Ireland (-174), Romania (-152), Lithuania (-130), Estonia (-114), and Germany (-110). In other countries, changes in the value of the indicator did not exceed $+/-100$.

CHART 2

Number of patent applications per $\$ 100$ bln GDP in analyzed countries; years 2011 and 2015

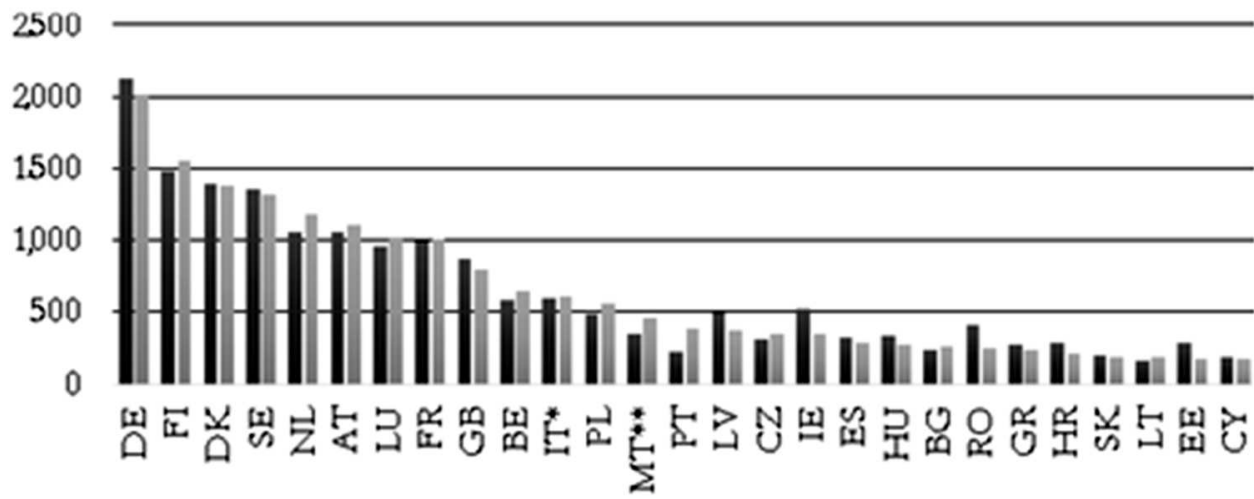

\section{घ2.011 $=2.015$}

* value of indicator in 2011 and 2014; ${ }^{* *}$ value of indicator in 2011 and 2013.

Source: own elaboration based on: [WIPO IP..., 2017].

The analyzed countries were characterized by considerable differences as regards the number of applications per $1 \mathrm{mln}$ inhabitants (chart 3), both in 2011 and in 2015. The highest value of an indicator in 2011 was observed in Germany (895), Luxembourg (876), Denmark (605), Finland (598), and Sweden (594). The lowest value of the indicator in the analyzed group was recorded in Lithuania (35), Bulgaria (38), and Cyprus (46). In 2015, five countries recorded the value of the indicator higher than 500. These were: Luxembourg (951), 
CHART 3

Number of patent applications per $1 \mathrm{mln}$ inhabitants in analyzed countries; years 2011 and 2015

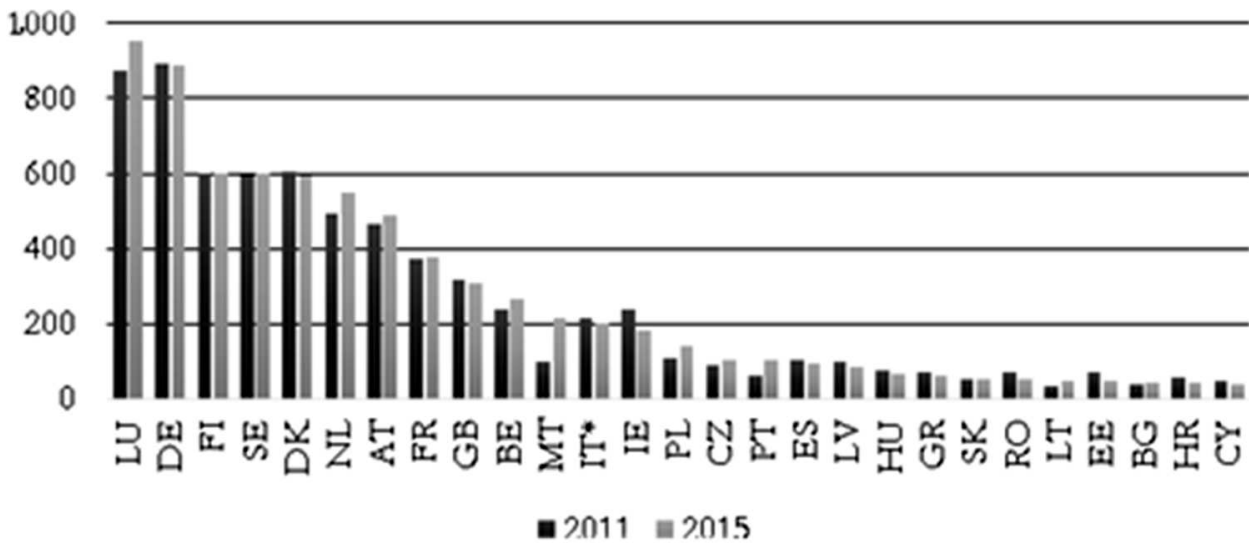

* value of indicator from the years 2011 and 2014

Source: own elaboration based on: [WIPO IP..., 2017].

Germany (887), Finland (600), Sweden (599), Denmark (597), and the Netherlands (549). The highest growth of the indicator's value in the years 2011-2015 was observed in Malta (+118), Luxembourg (+75), and the Netherlands (+58). Meanwhile, the highest decline was noticed in Ireland (-58). In other countries, changes in the value of the indicator did not exceed $+/-50$.

TABLE 4

Changes in indicator regarding number of patent applications per $\$ 100$ bln GDP in analyzed countries; years 2011-2015

\begin{tabular}{|c|l|l|c|c|}
\hline \multirow{2}{*}{$\begin{array}{c}\text { Group } \\
\text { number }\end{array}$} & \multicolumn{2}{|c|}{ Change in indicator value } & \multicolumn{2}{c|}{ Average dynamics of the indicator } \\
\cline { 2 - 5 } & \multicolumn{1}{|c|}{ Increase } & \multicolumn{1}{c|}{ Decrease } & $\mathrm{W}_{2015 / 2011}$ & $\mathrm{~W}_{\mathrm{G}}$ \\
\hline 1. & $\begin{array}{l}\text { BE, FR, LU, MT, } \\
\text { NL }\end{array}$ & GR, HU, ES & $+2.54 \%$ & $+1.37 \%$ \\
\hline 2. & $\begin{array}{l}\text { AT, BG, CZ, FI, } \\
\text { IT, LT, PL, PT }\end{array}$ & $\begin{array}{l}\text { HR, CY, DK, EE, } \\
\text { DE, IE, LV, RO, } \\
\text { SK, SE, GB }\end{array}$ & $-3.54 \%$ & $-1.44 \%$ \\
\hline
\end{tabular}

Source: own elaboration.

While analyzing the changes in the innovation levels of the analyzed countries as expressed by the output indicators based on the number of patents in years 2011-2015, divided into those with (group 1) and without (group 2) the Patent Box, it must be said that changes in both groups were not homogenous. The number of patent applications per \$100 bln GDP (table 4) increased 
in 5 countries from the first group, which accounted for $62.5 \%$ of the group. In 3 economies using Patent Box regimes in the analyzed time period, a reduction in the value of the indicator was recorded. Among 19 countries which did not have Patent Boxes, in the case of 8 economies increased values of the indicator were recorded, whereas in the case of 11 there were decreases in these values. The number of patents per $\$ 100$ bln GDP increased and decreased respectively in $42.1 \%$ and $57.9 \%$ of the countries from the second group. The value of the indicator increased on average by $2.54 \%$ in the countries from the first group in the years 2011-2015. In those countries which did not use Patent Boxes, the average trend (as regards change) was opposite and a decrease of $3.54 \%$ was recorded. The average annual rate of the indicator's growth in the analyzed time period ranged from $+1.37 \%$ to $-1.44 \%$ for the countries from the first group and the second group, respectively.

TABLE 5

\section{Changes in indicator regarding number of patent applications per $1 \mathrm{mln}$ inhabitants in analyzed countries; years 2011-2015}

\begin{tabular}{|c|l|l|c|c|}
\hline \multirow{2}{*}{$\begin{array}{c}\text { Group } \\
\text { number }\end{array}$} & \multicolumn{2}{|c|}{ Change in indicator value } & \multicolumn{2}{c|}{ Average dynamics of the indicator } \\
\cline { 2 - 5 } & \multicolumn{1}{|c|}{ Increase } & \multicolumn{1}{c|}{ Decrease } & $\mathrm{W}_{2015 / 2011}$ & $\mathrm{~W}_{\mathrm{G}}$ \\
\hline 1. & $\begin{array}{l}\mathrm{BE}, \mathrm{FR}, \mathrm{LU}, \mathrm{MT}, \\
\mathrm{NL}\end{array}$ & GR, HU, ES & $+14.22 \%$ & $+2.42 \%$ \\
\hline 2. & $\begin{array}{l}\text { AT, BG, CZ, FI, } \\
\text { LT, PL, PT, SK, } \\
\text { SE }\end{array}$ & $\begin{array}{l}\text { HR, CY, DK, EE, } \\
\text { DE, IE, IT, LV, } \\
\text { RO,GB }\end{array}$ & $+0.69 \%$ & $-0.37 \%$ \\
\hline
\end{tabular}

Source: own elaboration.

The number of patent applications per 1 million inhabitants increased in the years 2011-2015 in 5 of the countries with Patent Boxes. In three countries from this group, there was a decrease. On the other hand, in the economies without Patent Boxes, the changes were more homogenous: 9 countries recorded increases, while 11 others - decreases. The value of the indicator increased from 2011 to 2015 on average by $14.22 \%$ and $0.69 \%$, in countries with and without Patent Boxes, respectively. The average annual rate of growth ranged from $+2.42 \%$ and $-0.37 \%$ for the first and the second group, respectively.

\section{Conclusions}

Among tax incentives related to innovation activity, which are becoming increasingly significant in the economic policies of the European Union countries, such instruments as the Patent Box are particularly popular. While in 2000 this instrument was used in only two EU member states, by 2016 their number had increased almost seven-fold. 
The analysis of empirical data conducted in the research shows that both the average dynamics of the indicator reflecting the number of patents per $\$ 100$ bln GDP and that of the indicator showing the number of patents per 1 million inhabitants in the years 2011-2015 was considerably higher in countries which had adopted the Patent Box into their tax systems. The countries without this instrument were on average characterized by considerably lower or negative dynamics of innovation indicators based on the number of patents. Therefore, the conclusions which can be drawn from the analysis confirm the research hypothesis in accordance with which the Patent Box has an impact on the innovation levels of the European Union countries.

However, it needs to be emphasized that the character of the observed changes in both groups is not homogenous. Both among countries with Patent Boxes and without them, there were those which recorded increased values of the studied indicators and those which suffered a decline in the number of submitted patents. The author believes that this could have been caused by the differences in other determinants of the innovation levels of the analyzed countries, such factors as: legislation regulating the procedures of granting patents, innovation policies conducted in individual countries, or the quality of human capital may have a considerable impact on innovation levels.

When interpreting the conclusions from the research, it should be noted that the use of such an instrument as the Patent Box does not guarantee an increase in the innovation level, even though it does have an influence on it. A number of other determinants of the innovation potential, such as the existence of other instruments of innovation policy, or the quality of their functioning, can even contribute to a decrease of the innovation level in the country using this type of tax incentive. Therefore, it is necessary to emphasize the necessity to conduct further research into this subject, especially as regards interactions of Patent Box-type incentives with other instruments of innovation policy and all the remaining determinants of economic innovation.

\section{References}

A Study on RED Tax Incentives. Final Report, 2014, Working Paper no. 52, Taxation Papers, Taxation and Customs Union, European Commission.

Abramowitz M., 1956, Resource and Output Trends in the United States since 1870, Occasional Paper 52, National Bureau of Economic Research, Inc.

Aghion P., Howitt P., 1992, A Model of Growth through Creative Destruction, Econometrica, Vol. 60, Issue 2 (March).

Alstadsæter A., Barrios S., Nicodeme G., Skonieczna A. M., Vezzani A., 2015, Patent Boxes Design, Patents Location and Local RED, IPTS Working Papers on Corporate R\&D and Innovation - No. 6/2015, JRC Technical Reports, Joint Research Centre, European Commission. 
Arrow K. J., 1962, The Economic Implications of Learning by Doing, Review of Economic Studies, Vol. 29, No. 3 (June).

Bradley S., Dauchy E., Robinson L., 2015, Cross-Country Evidence on the Preliminary Effects of Patent Box Regimes on Patent Activity and Ownership, National Tax Journal, Vol. 68, Issue 4, pp. 1047-1072.

Corporate tax rates table, KPMG, electronic document, access mode: [https:// home.kpmg.com/xx/en/home/services/tax/tax-tools-and-resources/taxrates-online/corporate-tax-rates-table.html, date of entry: 09.04.2016].

Cyprus a tax efficient EU Intellectual Property location, 2012, PwC.

Design and Evaluating of Tax Incentives for Business Research and Development. Good practice and future developments. Final Report, 2009, Expert Group on Impacts of R\&D Tax Incentives, Directorate General - Research, European Commission, Brussels.

Global Research \& Development Incentives Group. February 2016, 2016, PwC.

Global Survey of RED Tax Incentives, 2011, Deloitte.

Grossman G. M., Helpman E., 1991, Quality Ladders in the Theory of Growth, Review of Economic Studies, Vol. 58, No. 1 (January).

Koimtzoglu I., Lytras N., 2015, Greece, [in:] Cahiers de droit fiscal international. Volume 100A: Tax incentives on Research and Development (RED), 2015 Basel Congress, International Fiscal Association (IFA).

Merril P., 2016, Innovation Boxes: BEPS and Beyond, National Tax Journal, Vol. 69, Issue 4.

Potencjał innowacyjny gospodarki: uwarunkowania, determinanty, perspektywy, 2016, Narodowy Bank Polski, NBP, Warszawa.

Romer P. M., 1986, Increasing Returns of Long-Run Growth, Journal of Political Economy, Vol. 94, No. 5 (October).

Schumpeter J., 1960, Teoria rozwoju gospodarczego, Państwowe Wydawnictwo Naukowe, Warszawa.

Solow R. M., 1957, Technical Change and the Aggregate Production Function, The Review of Economics and Statistics, Vol. 37, No. 3 (August).

Wildowicz-Giegiel A., Dziemianowicz R., 2015, The impact of tax incentives on the process of innovation creation in Polish economy, Proc. of the Third Intl. Conf. Advances in Social Science, Economics and Management Study, Institute of Research Engineers and Doctors, USA.

WIPO IP Statistics Data Center, WIPO, electronic document, access mode:

[https://www3.wipo.int/ipstats/index.htm, date of entry: 12.04.2016].

Worldwide RED incentives reference guide 2014-15, 2014, EY.

Worldwide RED incentives reference guide 2013-2014, 2013, EY.

2012 Global Survey of RED Tax Incentives, 2012, Deloitte.

2013 Global Survey of RED Tax Incentives, 2013, Deloitte.

2014 Global Survey of RED Tax Incentives, 2014, Deloitte.

2015 Global Survey of RED Incentives, 2015, Deloitte. 